\title{
29. DATA REPORT: CHEMICAL AND ISOTOPIC COMPOSITIONS OF PORE FLUIDS IN ACCRETED AND UNDERTHRUST SEDIMENTS OF THE NORTHERN BARBADOS RIDGE ${ }^{1}$
}

\author{
Miriam Kastner ${ }^{2}$ and Yan Zheng ${ }^{3}$
}

\begin{abstract}
The chemical and isotopic data reported here were carried out in our shore-based laboratories to complement the shipboard pore-fluid chemical data from the northern Barbados Ridge. The data include (1) pore-fluid bromide, iodide, and strontium concentrations and strontium and oxygen isotope ratios at both sites drilled, and (2) strontium, oxygen, and carbon isotope ratios, and $\mathrm{Sr}$ concentrations of vein-filling carbonates from Hole 948C. The data suggest that the fluid-rock reactions responsible for the source of the low $\mathrm{Cl}^{-}$fluid at the décollement occur arcward from the sites drilled, at greater burial depth than penetrated by drilling, and that organic matter-rich sediments are involved in the fluid-sediments reactions at the origin. This fluid has more radiogenic Sr isotopes than the in situ pore fluids and is enriched in $\mathrm{Sr}$ and I, and the carbon isotopes of the dissolved carbonate are strongly negative. The chemistry and isotopic compositions of the vein-filling carbonates indicate that they did not precipitate from the in situ pore fluid. A past pulse of fluid injection caused high pore-fluid pressure, hydrofracturing, and vein-filling carbonate mineralization. The present-day pore fluid is strongly overprinted by in situ diagenesis of volcanic glass, suggesting that no major episode of fluid flow has occurred in the recent past.
\end{abstract}

\section{INTRODUCTION}

The existence of large-scale fluid flow and fluid expulsion at convergent margins has been demonstrated by (1) tectonically induced rapid porosity reduction at the toes of accretionary complexes; (2) regionally variable heat flow; (3) pore-fluid chemical, isotopic, and temperature anomalies that can only be maintained by rapid fluid flow; and (4) widespread diffuse and/or channelized fluid venting through mud volcanoes or along thrust faults. High pore-fluid pressures are pervasive in convergent margins. These fluids play a central role in the deformational, thermal, and chemical evolution of convergent margins, and enhance diagenetic and metamorphic reactions. Fluids released from these reactions may be important for global geochemical budgets of particularly $\mathrm{H}_{2} \mathrm{O}, \mathrm{CO}_{2}$, and $\mathrm{CH}_{4}$.

The expelled fluids are characterized by variable chemical and isotopic compositions. Fresher-than-seawater fluids are ubiquitous in accretionary complexes; seawater dilutions of 10\%-64\% have been recorded. In the northern Barbados Ridge accreted and underthrust sediments, maximum seawater dilution of $\sim 20 \%$ was observed at Site 948, and only $\sim 10 \%$ at Site 949 , which is located closer to the thrust front. Mostly, dehydration of clay minerals caused the observed $\mathrm{Cl}^{-}$ dilution at both sites.

Deciphering the origin(s) of the geochemically complex pore fluids in sediments of accretionary complexes, and especially unraveling the causes for the positive and negative polarity seismic reflections at the décollement at Sites 948 and 949, respectively, requires having a spectrum of chemical and isotopic data. Accordingly, the geochemical and isotopic data reported here provide new insights into the origin and flow of fluids in the northern Barbados Ridge.

\section{MATERIALS AND METHODS}

All pore fluids analyzed were obtained by routine shipboard squeezing of whole-round sediment samples immediately after re-

${ }^{1}$ Shipley, T.H., Ogawa, Y., Blum, P., and Bahr, J.M. (Eds.), 1997. Proc. ODP, Sci. Results, 156: College Station, TX (Ocean Drilling Program).

${ }^{2}$ Scripps Institution of Oceanography, University of California, San Diego, La Jolla, CA 92093-0212, U.S.A. mkastner@ ucsd.edu

${ }^{3}$ Lamont-Doherty Earth Observatory of Columbia University, Palisades, NY 10964, U.S.A. trieval. The sediments were squeezed in titanium squeezers at ambient temperature and at pressures of 135-205 MPa $\left(140-210 \mathrm{~kg} / \mathrm{cm}^{2}\right)$. The pore-fluid samples were analyzed on board ship for a range of constituents. In addition to the trace elements analyzed at LamontDoherty Earth Observatory and summarized in Zheng and Kastner (Chapter 12, this volume), the shore-based pore-fluid analyses at Scripps Institution of Oceanography (SIO) emphasized bromide, iodide, and strontium concentrations, and strontium and oxygen isotope ratios. The results are summarized in Tables 1 and 2; the concentrations and isotope ratio depth profiles are shown in Figures 1 through 5. Bromide concentrations were measured using iodometric titration (Kremling, 1983) and iodide concentrations were measured spectrophotometrically (Pedersen, 1979) as modified by Gieskes et al. (1992). Precisions of the $\mathrm{Br}^{-}$and $\mathrm{I}^{-}$pore-fluid measurements are $\pm 5 \%$. Strontium concentrations were measured by atomic absorption (AA) spectroscopy and by isotope dilution mass spectrometry. The precision for $\mathrm{Sr}$ was $<3 \%$ by AA and $<0.1 \%$ by the latter method. Strontium and oxygen isotope ratios were determined by mass spectrometry. For the pore-fluid oxygen isotope analysis, the method of Bottinga and Craig (1969) was used with a precision of $0.06 \%$. Strontium isotopes were determined using standard mass spectrometric techniques. The $2 \sigma$ errors are given in Tables 1 and 2 . All measured ${ }^{87} \mathrm{Sr} /{ }^{86} \mathrm{Sr}$ ratios were normalized to a particular value $\left({ }^{86} \mathrm{Sr} /{ }^{88} \mathrm{Sr}\right.$ $=0.1194$ ) for a standard; the value obtained for the National Bureau of Standards (NBS) 987 measured in the SIO laboratory is 0.710255 , with a $2 \sigma$ error of 16 .

Vein-filling carbonates were analyzed for $\mathrm{Sr}$ concentrations and strontium, oxygen, and carbon isotope ratios. The oxygen and carbon isotopes of the carbonates were analyzed following the method of McCrea (1950). The precision for oxygen was $0.04 \%$ and for carbon $0.03 \%$. The isotopic results are reported in the conventional fashion as $\delta^{18} \mathrm{O}$ and $\delta^{13} \mathrm{C}$ in per mil relative to PeeDee Belemnite (PDB).

\section{OVERALL RESULTS}

Similar to $\mathrm{Cl}^{-}$, no other geochemical process except for evaporation or dilution alters the $\mathrm{Br}^{-}$concentration. Therefore, it has often been used as a sensitive conservative tracer along with $\mathrm{Cl}^{-}$(i.e., Holser 1979; Carpenter, 1978). Sediment organic matter becomes enriched in iodine from oxidation-reduction processes of $\mathrm{IO}_{3}{ }^{-}$and $\mathrm{I}^{-}$at the sediment-water interface (i.e., Price and Calvert, 1973; Kennedy 
Table 1. Chemical and isotopic compositions of pore-fluid samples from Site 948.

\begin{tabular}{|c|c|c|c|c|c|c|c|}
\hline $\begin{array}{l}\text { Core, section, } \\
\text { interval }(\mathrm{cm})\end{array}$ & $\begin{array}{l}\text { Depth } \\
\text { (mbsf) }\end{array}$ & $\begin{array}{c}\mathrm{Br}(\mu \mathrm{M}) \\
(\mathrm{Spec})\end{array}$ & $\begin{array}{l}\mathrm{I}(\mu \mathrm{M}) \\
(\mathrm{Spec})\end{array}$ & $\begin{array}{c}\mathrm{Sr}(\mu \mathrm{M}) \\
(\mathrm{AAS})\end{array}$ & ${ }^{87} \mathrm{Sr} /{ }^{86} \mathrm{Sr}$ & $2 \sigma$ & $\begin{array}{c}\delta^{18} \mathrm{O} \\
(\% \circ \text { SMOW })\end{array}$ \\
\hline \multicolumn{8}{|l|}{$156-948 \mathrm{C}-$} \\
\hline $1 \mathrm{H}-4,143-150$ & 6.0 & 839.5 & 38.5 & 102.2 & & & 0.12 \\
\hline $2 X-4,130-150$ & 426.7 & 842.4 & 26.6 & 206.7 & & & -1.94 \\
\hline $3 X-5,120-150$ & 437.9 & 863.7 & 28.3 & 201.0 & 0.707318 & 20 & -1.81 \\
\hline $5 \mathrm{X}-2,120-150 \#$ & 452.7 & 855.0 & 33.0 & 196.2 & & & -1.61 \\
\hline $6 \mathrm{X}-4,118-150 \#$ & 465.2 & 844.8 & 43.2 & 192.2 & 0.707252 & 15 & -1.62 \\
\hline $7 X-6,120-150$ & 477.8 & 789.9 & 44.1 & 198.6 & & & -1.94 \\
\hline $8 \mathrm{X}-3,110-150 \#$ & 483.0 & 804.5 & 45.5 & 182.5 & & & -2.03 \\
\hline $8 \mathrm{X}-6,120-150$ & 487.6 & 791.6 & 52.4 & 197.8 & 0.707290 & 14 & -2.08 \\
\hline $9 \mathrm{X}-4,115-150$ & 494.2 & 757.8 & 67.2 & 183.3 & 0.707336 & 17 & -2.09 \\
\hline $10 \mathrm{X}-3,110-150$ & 502.4 & 702.4 & 164.6 & 191.4 & 0.707481 & 17 & -2.09 \\
\hline $11 \mathrm{X}-3,120-150$ & 512.1 & 820.0 & 125.0 & 215.5 & 0.707609 & 14 & -1.74 \\
\hline $12 \mathrm{X}-4,110-150 \#$ & 523.2 & 871.6 & 54.4 & 219.1 & & & -1.89 \\
\hline $13 X-4,115-150$ & 532.6 & 940.9 & 41.1 & 223.5 & 0.707658 & 16 & -1.93 \\
\hline $14 \mathrm{X}-5,120-150 \#$ & 543.5 & 945.4 & 28.6 & 242.0 & & & -1.73 \\
\hline $15 \mathrm{X}-6,110-150$ & 554.2 & 930.2 & 23.8 & 256.5 & & & -2.23 \\
\hline $16 \mathrm{X}-2,110-150$ & 557.1 & 928.3 & 23.7 & 267.8 & & & -2.29 \\
\hline $17 \mathrm{X}-2,120-150 \#$ & 567.0 & 946.4 & 20.6 & 269.8 & 0.707638 & 17 & -2.13 \\
\hline $17 \mathrm{X}-5,0-040^{*}$ & 570.3 & 940.6 & 20.4 & 288.7 & & & -2.35 \\
\hline $18 \mathrm{X}-4,110-150$ & 579.1 & 969.5 & 19.5 & 288.7 & & & -2.32 \\
\hline $19 \mathrm{X}-4,110-150$ & 588.6 & 924.4 & 21.6 & 304.3 & 0.707676 & 18 & -2.59 \\
\hline
\end{tabular}

Notes: $*$ = He sample excess interstitial water. \# = squeezed after sealing and up to $24 \mathrm{hr}$ storage in refrigerator.

Table 2. Chemical and isotopic compositions of pore-fluid samples from Site 949.

\begin{tabular}{|c|c|c|c|c|c|c|c|}
\hline $\begin{array}{l}\text { Core, section, } \\
\text { interval }(\mathrm{cm})\end{array}$ & $\begin{array}{l}\text { Depth } \\
\text { (mbsf) }\end{array}$ & $\begin{array}{c}\mathrm{Br}(\mu \mathrm{M}) \\
(\mathrm{Spec})\end{array}$ & $\begin{array}{l}\mathrm{I}(\mu \mathrm{M}) \\
(\mathrm{Spec})\end{array}$ & $\begin{array}{l}\mathrm{Sr}(\mu \mathrm{M}) \\
(\mathrm{AAS})\end{array}$ & ${ }^{87} \mathrm{Sr} /{ }^{86} \mathrm{Sr}$ & $2 \sigma$ & $\begin{array}{c}\delta^{18} \mathrm{O} \\
(\% \circ \text { SMOW })\end{array}$ \\
\hline $\begin{array}{l}156-949 \mathrm{~A}- \\
1 \mathrm{H}-1,143-150\end{array}$ & 1.5 & 905.7 & 2.3 & 90.9 & & & 0.41 \\
\hline $\begin{array}{l}\text { 156-949B- } \\
1 \mathrm{X}-1,120-150 \\
2 \mathrm{X}-3,0-40 \\
2 \mathrm{X}-5,110-150 \\
3 \mathrm{X}-5,110-150 \\
4 \mathrm{X}-1,125-150 \\
5 \mathrm{X}-2,110-150^{*} \\
5 \mathrm{X}-4,110-150 \\
7 \mathrm{X}-2,110-150 \\
7 \mathrm{X}-6,110-150 \\
13 \mathrm{X}-1,110-150 \\
14 \mathrm{X}-2,0-40 \# * \\
14 \mathrm{X}-5,110-150 \\
15 \mathrm{X}-2,110-150 \\
15 \mathrm{X}-5,110-150 \\
17 \mathrm{X}-\mathrm{CC}, 2-8 \\
19 \mathrm{X}-2,60-100 \\
22 \mathrm{X}-5,110-150 \\
25 \mathrm{H}-3,110-150\end{array}$ & $\begin{array}{l}245.5 \\
257.0 \\
261.1 \\
270.8 \\
274.5 \\
285.6 \\
288.6 \\
304.9 \\
310.9 \\
351.5 \\
355.8 \\
358.6 \\
362.7 \\
367.2 \\
378.6 \\
401.1 \\
434.7 \\
460.7\end{array}$ & $\begin{array}{l}882.6 \\
875.3 \\
854.0 \\
860.3 \\
849.3 \\
888.6 \\
892.5 \\
885.3 \\
832.1 \\
840.4 \\
836.3 \\
\\
728.4 \\
833.9 \\
951.4\end{array}$ & $\begin{array}{r}33.4 \\
46.7 \\
58.0 \\
56.7 \\
\\
64.7 \\
28.4 \\
33.5 \\
38.7 \\
\\
44.9 \\
52.6 \\
55.7 \\
\\
161.6 \\
87.1 \\
22.6\end{array}$ & $\begin{array}{l}203.4 \\
205.0 \\
212.3 \\
201.8 \\
201.0 \\
207.5 \\
194.6 \\
220.7 \\
226.8 \\
219.5 \\
219.5 \\
216.3 \\
218.7 \\
217.1 \\
236.4 \\
231.6 \\
258.5 \\
296.7\end{array}$ & $\begin{array}{l}0.707508 \\
0.707647\end{array}$ & $\begin{array}{l}16 \\
14\end{array}$ & $\begin{array}{l}-2.02 \\
-2.06 \\
-1.99 \\
-1.97 \\
-2.06 \\
-1.88 \\
-2.01 \\
-1.47 \\
-1.85 \\
-2.01 \\
-2.04 \\
-2.02 \\
-1.14 \\
-2.04 \\
-1.90 \\
-2.24 \\
-2.23 \\
-2.28\end{array}$ \\
\hline $\begin{array}{l}\text { 156-949C- } \\
\text { 2R-CC, 5-10 } \\
\text { 4R-1, 0-4 } \\
\text { 6R-CC, } 8-15^{* *} \\
\text { 7R-1, 80-90 }\end{array}$ & $\begin{array}{l}415.0 \\
425.2 \\
453.6 \\
455.0\end{array}$ & 914.7 & 31.3 & $\begin{array}{l}242.0 \\
233.2 \\
240.4 \\
286.2\end{array}$ & 0.707723 & 17 & $\begin{array}{l}-1.89 \\
-1.66 \\
-1.38\end{array}$ \\
\hline
\end{tabular}

Notes: $*$ = He samples. \# = some extra sample available. $* *=$ contaminated by drill water.

and Elderfield, 1987; Martin et al., 1993). These processes only occur when bottom water is oxygenated, as it is near trenches of subduction zones. After burial, reactions between fluids and organic matter-rich sediments may release the trapped iodine. Because the $\mathrm{Cl}^{-}$concentration of the pore fluids at Sites 948 and 949 varies significantly, especially at the décollement zone, and the sediments recovered are rather poor in organic matter, comparisons between the $\mathrm{Cl}^{-}$and $\mathrm{Br}^{-}$with $\mathrm{I}^{-}$ concentrations of the pore fluids could help to unravel the source of the low- $\mathrm{Cl}^{-}$fluid.

The dissolved sulfate concentration-depth profile, especially pronounced at Site 948, suggests that a sediment enriched in organic matter exists in the underthrust section below the drilled depth (Ogawa, Shipley, Blum, et al., 1995). The Mo and $\mathrm{Zn}$ concentrations of the pore fluids (Zheng and Kastner, Chapter 12, this volume) and the light carbon isotopes of the vein-filling carbonate, given in Table 2 and discussed in Labaume et al. (Chapter 5, this volume), strongly imply that the reactions between the low- $\mathrm{Cl}^{-}$fluid and sediments at the site of origin involve an organic matter-rich sediment. The data in
Tables 1 and 2 support the conclusion that the low- $\mathrm{Cl}^{-}$fluid at and above the décollement has reacted with an organic matter-rich sediment not encountered during drilling at Sites 948 and 949.

$\mathrm{Sr}$ concentrations provide information on the composition of the solids that react with the fluid. Reactions of fluid with volcanic material and most detrital silicates, other than quartz, would raise its $\mathrm{Sr}$ concentrations. The Sr concentrations, although lower at the décollement at both sites (Fig. 3), are only half as diluted as the $\mathrm{Cl}^{-}$(Tables 1,2 ), indicating that the low- $\mathrm{Cl}^{-}$fluid is enriched in Sr. Most importantly, however, because $\mathrm{Sr}$ isotopes do not fractionate during geochemical processes, they clearly indicate the sources and sinks of the materials involved in the processes. The pore-fluid $\mathrm{Sr}$ isotope data of both sites are significantly less radiogenic (lower ${ }^{87} \mathrm{Sr} /{ }^{86} \mathrm{Sr}$ ratios) than modern or contemporaneous seawater $\mathrm{Sr}$ isotope values (e.g., Burke et al., 1982; Tables 1, 2; Fig. 4); volcanic glass alteration is responsible for this shift. Based on a mixing plot of ${ }^{87} \mathrm{Sr} /{ }^{86} \mathrm{Sr}$ vs. $1 / \mathrm{Sr}$ (Kastner et al., Chapter 25, this volume), the deeper sourced fluid feeding the low- $\mathrm{Cl}^{-}$conduit is clearly significantly more radiogenic 

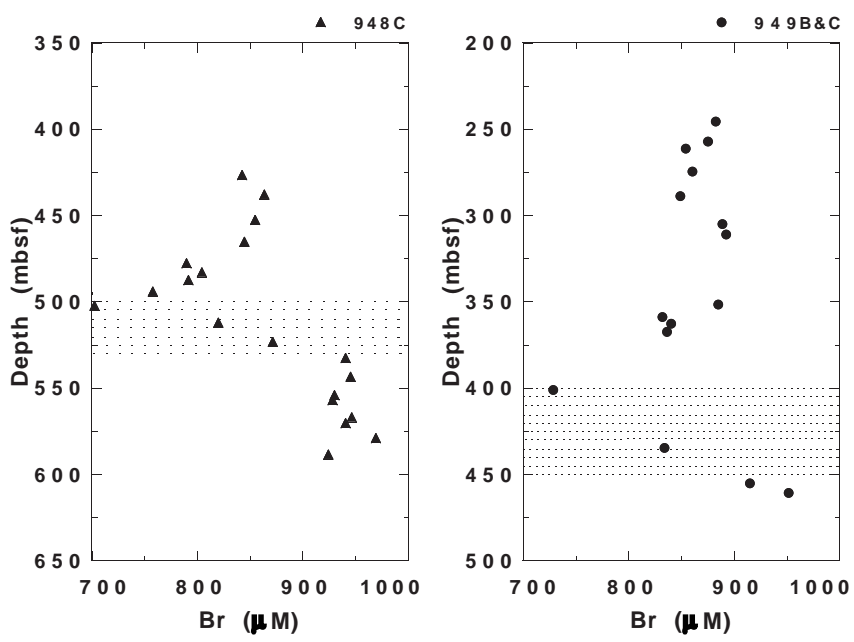

Figure 1. Depth profiles of bromide concentrations in pore fluids from Sites 948 and 949. The dashed areas delineate the décollement zone.
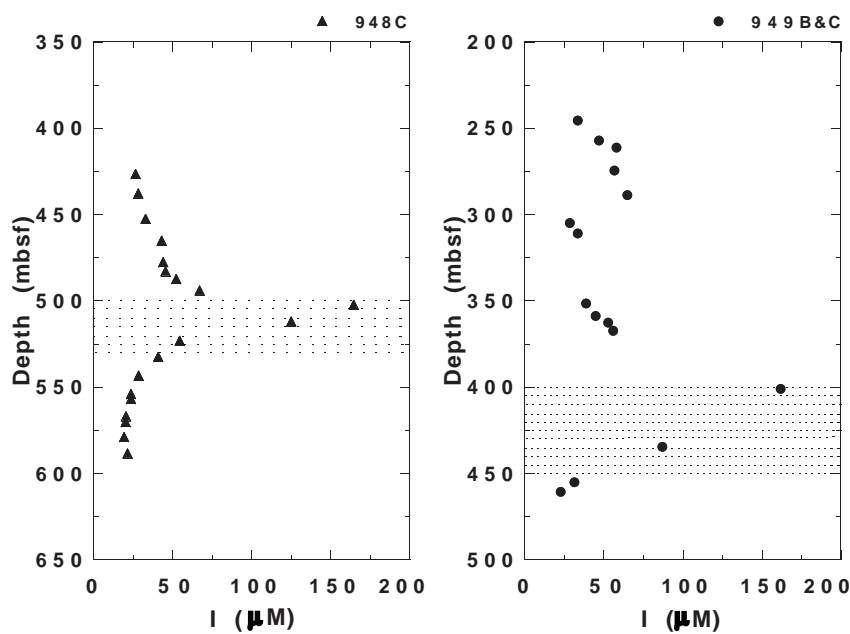

Figure 2. Depth profiles of iodide concentrations in pore fluids from Sites 948 and 949. The dashed areas delineate the décollement zone.
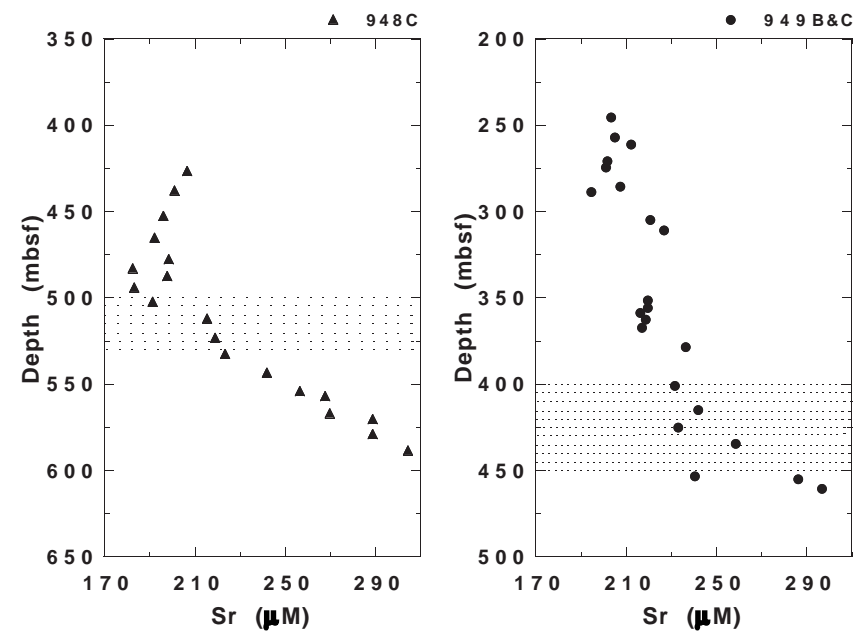

Figure 3. Depth profiles of strontium concentrations in pore fluids from Sites 948 and 949 . The dashed areas delineate the décollement zone.
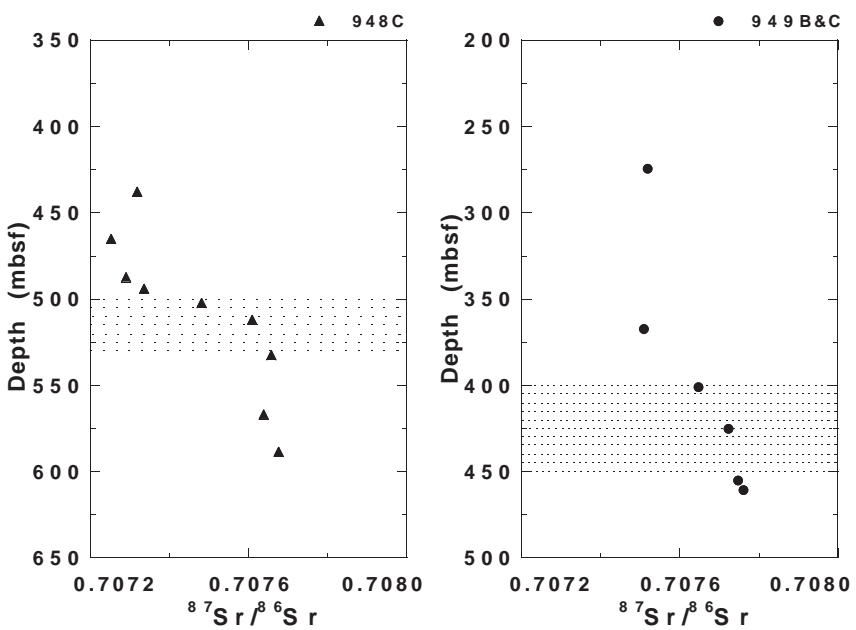

Figure 4. Depth profiles of strontium isotope ratios in pore fluids from Sites 948 and 949 . The dashed areas delineate the décollement zone.
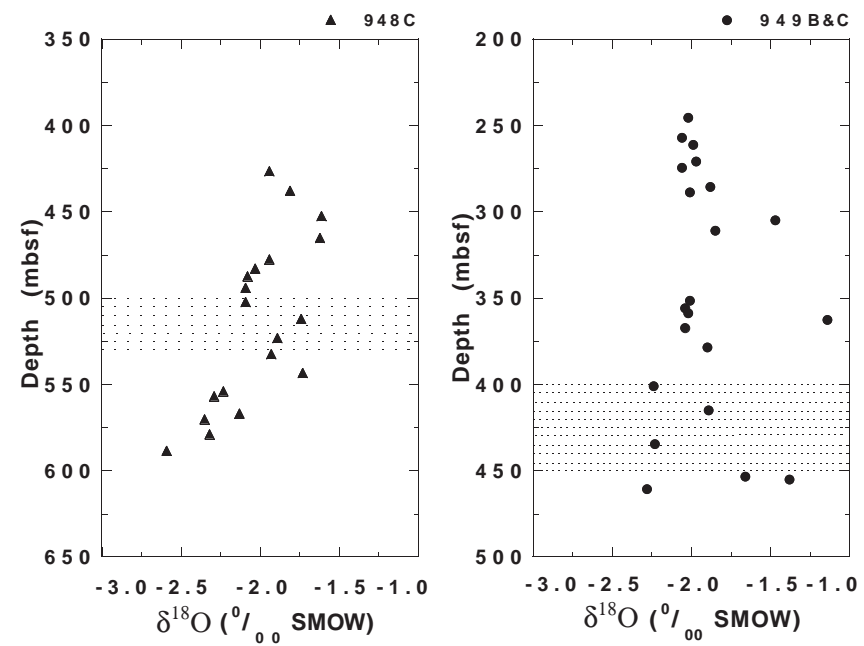

Figure 5. Depth profiles of oxygen isotope ratios in pore fluids from Sites 948 and 949. The dashed areas delineate the décollement zone.

than the in situ pore fluids. The slightly negative oxygen isotope values in Tables 1 and 2 and Figure 5 reflect in situ low to moderate temperature of formation of mostly smectite from volcanic glass alteration, which is also responsible for the non-radiogenic $\mathrm{Sr}$ isotopes.

The data in Table 3 discussed in Labaume et al. (Chapter 5, this volume) show that the vein carbonates have precipitated from a fluid chemically and isotopically distinct from the present-day in situ pore fluid or from contemporaneous seawater.

\section{REFERENCES}

Bottinga, Y. and Craig, H., 1969. Oxygen isotope fractionation between $\mathrm{CO}_{2}$ and water and the isotopic composition of marine atmospheric $\mathrm{CO}_{2}$. Earth Planet. Sci. Lett., 5:285-295.

Burke, W.H., Denison, R.E., Hethrington, E.A., Koepnick, R.B., Nelson, H.F. and Otto, J.B., 1982. Variation of seawater ${ }^{87} \mathrm{Sr} /{ }^{86} \mathrm{Sr}$ throughout Phanerozoic time. Geology, 10:515-519.

Carpenter, A.B., 1978. Origin and chemical evolution of brines in sedimentary basins. Oklahoma Geol. Surv. Circular, 79:60-77.

Gieskes, J.M., Gamo, T. and Brumsack, H., 1992. Chemical methods for interstitial water analyses aboard JOIDES Resolution. ODP Technical Note, 15. 
Holser, W.T., 1979. Trace elements and isotopes in evaporites. Rev. Mineral., 6:295-346.

Kennedy, H.A. and Elderfield, H., 1987. Iodine diagenesis in pelagic deepsea sediments. Geochim. Cosmochim. Acta, 51:2489-2504.

Kremling, K., 1983. Determination of major constituents: bromide. In Methods of Seawater Analysis, Grasshoff, K., ed., Verlag-Chemie.

Martin, J.B., Gieskes, J.M., Torres, M. and Kastner, M., 1993. Bromine and iodine in Peru margin sediments and pore fluids: implications for fluid origin. Geochim. Cosmochim. Acta, 57:4377-4389.

McCrea, J.M., 1950. On the isotopic chemistry of carbonates and paleotemperature scale. J. Chem. Phys., 18:849-857.

Ogawa, Y., Shipley, T.H., Blum, P., et al., 1995. Proc. ODP, Init. Repts., 156: College Station, TX (Ocean Drilling Program).
Pedersen, T.F., 1979. The geochemistry of sediments of the Panama Basin, eastern equatorial Pacific Ocean. Ph.D. dissertation, Univ. Edinburgh.

Price, N.B. and Calvert, S.E., 1973. The geochemistry of iodine in oxidized and reduced recent sediments. Geochim. Cosmochim. Acta, 37:21492158.

Date of initial receipt: 31 January 1996

Date of acceptance: 17 July 1996

Ms 156SR-026

Table 3. Strontium concentration and strontium, oxygen, and carbon isotope ratios of vein-filling carbonates, Site 948.

\begin{tabular}{|c|c|c|c|c|c|c|}
\hline \multicolumn{7}{|c|}{ Carbonate veins, ODP Site 948} \\
\hline Macro-appearance & Minerology & $\begin{array}{c}\mathrm{Sr} \\
(\mathrm{ppm})\end{array}$ & ${ }^{87} \mathrm{Sr} /{ }^{86} \mathrm{Sr}$ & $2 \sigma$ & $\begin{array}{c}\delta^{18} \mathrm{O} \\
(\% \circ \mathrm{PDB})\end{array}$ & $\begin{array}{c}\delta^{13} \mathrm{C} \\
(\% \circ \mathrm{PDB})\end{array}$ \\
\hline Gray & $\begin{array}{l}\text { Rhodochrosite \& } \\
\text { Mg-kutnohorite }\end{array}$ & 23 & 0.708131 & 16 & $\begin{array}{l}5.21 \\
5.31\end{array}$ & $\begin{array}{l}-3.30 \\
-3.29\end{array}$ \\
\hline Pink & $\begin{array}{l}\text { Mg-kutnohorite \& } \\
\text { rhodochrosite }\end{array}$ & 428 & $\begin{array}{l}0.708385 \\
0.708320 \\
0.708363\end{array}$ & $\begin{array}{l}16 \\
13 \\
15\end{array}$ & $\begin{array}{l}3.61 \\
3.60 \\
3.65\end{array}$ & $\begin{array}{l}-5.97 \\
-7.16 \\
-7.10\end{array}$ \\
\hline White & $\begin{array}{l}\text { Dolomite \& } \\
\text { Mg-kutnohorite }\end{array}$ & 868 & 0.708567 & 16 & $\begin{array}{l}3.09 \\
3.09\end{array}$ & $\begin{array}{r}-9.33 \\
*-8.91\end{array}$ \\
\hline Décollement pore fluid & & 16 & 0.707336 & 17 & -2.09 & \\
\hline
\end{tabular}

Note: $*$ very little gas. 